\title{
Research Quality (per academic/scientific publication)
}

Miguel Abambres

\section{Definitions}

Academic/Scientific Impact of a Publication

Defined by Miguel Abambres

Social Impact of a Publication

Defined by Miguel Abambres

Academic/Scientific Impact of a Publication "+" Social Impact of a Publication

As in 'Bye Bye Peer-Reviewed Publishing' [1]

References

1. ^ https://www.researchgate.net/publication/332626809 Bye Bye PeerReviewed Publishing 